\title{
North Africa: Calculus of Policy
}

\author{
By William H. Lewis
}

\begin{abstract}
The North African littoral assumed special importance for the United States after the landing of American forces in November 1942. While the strategic-military weight assigned to the area by the West declined after 1956, with the growth of local nationalist movements and the relinquishment of French protectorate authority over Morocco and Tunisia, North Africa has acquired a unique political and economic significance and relevance for Western interests. The United States, for its part, has sought to support the nation-building efforts of local governments without undue regard to their political philosophies or foreign policy orientations. Measured in pragmatic as well as historic terms, the American contribution has been both constructive and enduring.
\end{abstract}

William H. Lewis has been associated with North African affairs since 1952. He conducted his doctoral research in the area under Ford Foundation sponsorship and has since held appointments in the Department of State and in the academic communityUniversity of Michigan, Georgetown University, and Johns Hopkins. Dr. Lewis has coauthored a number of books on Middle Eastern and African affairs and is a frequent contributor to professional journals. 
$\mathrm{T}$ HE prevalent atmosphere of pessimism that characterizes our foreign studies community is not new to academia. We have witnessed similar moods shortly after World War I and in the period immediately preceding the Second World War. In both instances, the withdrawal of this country from a forthright international role appeared to lie at the heart of this pessimism.

Unique today is the fact that public and congressional opinion has shifted from uncritical support for the exercise of great power responsibility, towards a reluctance to accept new obligations and commitments. Accompanying the feeling that the era of confrontation with communist nations is at an end, is growing sentiment for a moratorium on the taking of fresh initiatives abroad. Since we have strained our human and material resources, and because the United States is powerless to cope with the forces that are afoot in the international arena, so the argument runs, our preferred posture should be one of restraint and the avoidance of tension.

In reality, of course, tension is very much a part of our lives, individual and communal. It is a function of modern technology and the human spirit. As a result, one should be able to agree with the hero of Candide who, upon his return from the battlefields of the Thirty Years War, engaged in a debate with his mentor Pangloss over the lessons to be learned from that great war. He disagreed with the latter's unworldly contention that everything is for the best in the best of all possible worlds, and Pangloss's admonition, "Now let us sit down and talk about perfect harmony." Candide replied: "No. Let us not talk about harmony because there is no such thing. But let us try, before we die, to make sense out of life."
The Maghrib: General Perspective

The question of American commitments in North Africa has been debated with less intensity than has been the case with most other geographic regions. In part, this can be attributed to our lack of identification with the Maghrib $a l-a k s a$-Arabic for "land of the farthest west." Rarely a part of the main stream of American diplomatic consciousness before 1939, the Maghrib became a focal point only in November 1942 with the landing of American troops in a major military operation hopefully christened Torch and the subsequent historic meeting of President Roosevelt with the ruler of Morocco, Muhammad V, at Casablanca.

According to one of his progeny, the President offered unsolicited assurances to the Moroccan Monarch concerning his country's future sovereignty. History records, however, that Morocco, together with Algeria and Tunisia, returned to full French control on the conclusion of World War II. Nevertheless, our contacts with the region were not to pass unnoticed. The United States retained control over Wheelus Air Force Base outside Tripoli after the cessation of hostilities, and was a strong proponent of Libyan independence when the fate of that former Italian colony came under consideration in United Nations councils.

During the initial post-1945 period of American involvement in Middle Eastern affairs, a number of paradoxes developed, however. In contrast to the ease with which we accommodated to the return of French colonial rule in the Maghrib, the United States declared itself ready to uphold the independence and territorial integrity of states elsewhere in the Mediterranean. Under the terms of the Truman Doctrine, the 
United States offered "to support free peoples who are resisting attempted subjugation by armed minorities or by outside pressures" and to support them in efforts "to work out their own destinies in their own way."

Despite this enunciation of principle, U.S. foreign policy followed a uniquely different path in North Africa. For example, as a result of the apparent threat of Soviet military aggrandizement in Western Europe, while American forces were engaged in Korea, an agreement was concluded with the government of France in 1950 to construct and maintain Strategic Air Command bases in the French Protectorate of Morocco, without formal consultation with King Muhammad V. Moreover, three years later, Washington was otherwise occupied when the French Resident General at Rabat determined that Muhammad V had become too closely identified with the Moroccan nationalist movement, ousted him on August 20, 1953, and dispatched the King into exile.

By contrast, the United States proved unstinting in its support of Idris I, who, from the date of Libyan independence in December 1951, served as his country's political rudder and stabilizing influence. This apparent contradiction in approach left more than a handful of observers perplexed about American policy in North Africa. Some, wounded by apparent contradiction, were mindful of a historical parallel in the appointment of a noble lord to the British secretaryship of state for foreign affairs during the nineteenth century. The appointee, as the French observed, seemed an admirable candidate, parceque les affaires lui seront étrangères.

However, the seeming contradictions of U.S. policy were more apparent than real. This was a period of nationalist awakening in much of the Third World, a time of social disorganization and of revolutionary change. The prism of
American policy had to take these factors into account, as well as to assess their relationship to broad American strategies and interests in the Mediterranean region as a whole.

Within this context, security interests were bound to overrule moral precepts. In a period of fluidity, overshadowed by the Korean conflict, tough-mindedness was certain to prevail. With the passage of time, however, it became apparent to Europe that the preservation of empire in the face of stern nationalist opposition was a wasting venture. In due course, France ended its imperium in North Africa, in part as a result of nagging U.N. resolutions, but primarily because the costs of protracted conflict were proving too costly. It would not be uncharitable to note that during much of this early period the United States played only a marginal role in the final resolution of the colonial issue.

\section{The Nation-Building Process}

After many years in the shadows, the Maghrib began to emerge on the world scene with startling urgency in 1950. The rapid development of nationalist movements, the creation of urban-based labor organizations, and the mobilization of rural communities behind the nationalist urge for independence were indicative of the ferment that was spreading through the region. Dramatic events hallmarked the early period including the exile of Habib Bourguiba from Tunisia, the Casablanca riots of December 1952, the outbreak of the Algerian conflict in November 1954, the French-Tunisian Accords of June 1955 granting the latter internal autonomy, the Oued Zem massacres of August 1955, the return of King Muhammad V to the Moroccan throne later in 1955, and the French decision to grant Morocco and Tunisia independence in March 1956. This was followed six years later, 
after considerable travail, by a similar dispensation for Algeria.

Independence came in a springtide of popular enthusiasm, but the leaders of each nation found that governmental responsibility was more than a question of directing legions of loyal supporters.

In Morocco, the number of problems that confronted Muhammad V, the Istiqlal party, and the Union Marocaine $d u$ Travail were staggering. The national administration, once largely the domain of French officialdom, had to be rehabilitated. For its part, the monarchy had to legitimize its rule, apportion cabinet portfolios among competing political parties, and reunite Moroccan society, which had been divided by forty years of colonial partition. Moreover, new cadres of intermediate and higher level administrators and technicians had to be found; teachers were needed to meet the growing demand for education; and political life had, perforce, to be stabilized in the aftermath of decolonization.

Tunisia, like Morocco, was a nation en rodage in 1956. Unlike Morocco's Istiqlal leadership, however, Habib Bourguiba had fashioned his NeoDestour party into a dominant political entity. In the process, he had created a "unilineal oligarchy" which mobilized the Tunisian people behind the NeoDestour. For the overwhelming majority, Bourguiba's leadership proved masterful, almost charismatic. The President had attained such eminence that he was quickly able to introduce sweeping social, economic, and political reforms. Some proved so iconoclastic that Bourguiba and his Destourians were increasingly referred to as the modern-day Kemalists of the Middle East.

On the other hand, few governments created since World War II faced greater problems in establishing and maintaining their authority than Algeria. At independence, in mid-1962,
Algeria had few conventions or institutions to guide her through her difficult postwar period of rehabilitation. A sturdy democratic tradition had not been implanted; politics had largely been the preserve of the Europeans. Experience in the art of governing was limited, and no meaningful effort had been made during the seven-year period of the liberation struggle to organize cadres of administrators, technicians, and bureaucrats. Finally, no polititically integrative mechanism emerged from the early nationalist experience. Unlike Tunisia's Destourian-Socialist party, the aura of legitimacy that surrounded the National Liberation Front (FLN)-the engine of nationalist revolution from 1954 to 1962 - was dissipated in the ensuing scramble for power.

In mid-1962 Algeria found herself on the threshold of renewed conflict. The principals in this second act of violence were not the European settlers (colons), however. The vast majority of these, approximately 850 thousand out of a total of 1 million, had fled out of fear of retribution by Algeria's 9 million Muslims. The principals were the founders and leaders of the Algerian revolution, men who, at the hour of triumph, fell into disagreement over the distribution of power and ignored what should have been a more compelling imperative-the rehabilitation of a war-torn society. Thus, the sorting-out process was not completed until June 1965, when Colonel Houari Boumedienne deposed Ahmed Ben Bella and assumed the mantle of leadership.

The latter event materialized more than ten years after Libya had been granted independent status under U.N. auspices. In the intervening period, Libya had moved from the position of international ward to that of a prosperous, going national entity. Accomplished without trauma and political upheaval, Libya's transition followed a 
course prescribed by her venerable monastic sovereign, Idris I. A man of deep religious conviction, the King insisted upon his right to direct, to adjudicate, and to set the pace of political growth. The distinctive feature of the absolutist system formed by Idris was its isolation from the society at large. The power elite consisted of the King, a small coterie of retainers in the court entourage, and those among his ministers who enjoyed favored status.

A particularly significant feature of the absolutist system was its seeming lack of viability. The King had produced no male issue, and the question of succession was perennially clouded. The heir-apparent, a relative named Hasan al-Ridha, was a lackluster personality who was not highly regarded by the aging septuagenarian ruler. The King had actually signaled his intention on several occasions to recommend the creation of a republic prior to his demise.

Given the fragility of the Idrisid system, its ability to survive for more than seventeen years may be difficult to comprehend. Part of the answer was undoubtedly to be found in the fragmented nature of Libyan society at independence. While the ruling elite agreed on most public issues, the Libyan public lacked any consensus. The latter was relatively ill-informed; political parties, moreover, were proscribed by the King; what labor union activity existed was carefully regulated by the ruling oligarchy. The threat of coercion always lurked in the background. In addition, traditional society was pluralistic in a profoundly divisive sense. As a result, the monarchy could play off competing tribal groups in Cyrenaica, buy off vying merchant factions in Tripoli and Benghazi, and harass hard-core irreconcilables. Through these devices, the oligarchy could control the resources of power and influence.

\section{Purposes and Goals}

Convention dictates that we weigh the efficacy of our policies very much like junior accountants. Policy consists of profit and loss columns in which debits and credits are entered. Within this context, resources must be allocated prudently to achieve maximum objectives, programs should be balanced against finite goals, and competing priorities must be arranged in an orderly and coherent pattern. In the real world, of course, policy cannot be treated as a ledger in which entries are totaled in multiple colors - red for losses, blue for gains, grey for undecided benefits.

In a mutated world, policies, goals, and objectives tend to produce only limited advantages and gains unless they are rooted in purposes that are shared by a number of nations. Jointly shared conceptions help to avoid the transformation of policies into a series of unrelated improvisations.

In our dealings with the new North African states, we have shared few common habits of thought. Clearly, we have no desire to substitute ourselves for Europe in a proconsular relationship; nor have we sought clients in the Maghrib. Instead, we have offered our support and our assistance to the leaders of the new states in their efforts to grapple with the problems of political development and economic growth. Moreover, the United States has played a singular role in seeking to resolve local disputes, in backing regional co-operation, and in bolstering North African ties with the Western world. In short, over the past decade we have dealt with the Maghrib in pragmatic, low-key terms; our essential goal has been to avoid the polarization of forces in the area; the bulk of our efforts has been directed toward collective action to resolve common problems.

In part, U.S. policies in the decade 
of the sixties has reflected the altered strategic importance of North Africa in the Mediterranean power balance. Technological advances in the missile field, for example, reduced the significance of our bases and landing facilities in the Maghrib. This factor, together with rising nationalism, led to the liquidation of virtually all Western facilities over the past decade; U.S. air bases in Morocco were removed in 1963; the French evacuation was completed the previous year; in the case of Tunisia, French bases were evacuated by 1963 . While the French-Algerian agreement of 1962 accorded French forces special facilities for a period of up to fifteen years, all had gone before the decade was out. British and American withdrawal from Libya followed shortly after the deposition of King Idris by military officers in September 1969.

During this same period, North Africa's decline in strategic military importance was partially offset by the dramatic increase in the area's output of oil and various other mineral resources. Algeria and Libya, in particular, have increased their production of oil and petrochemicals at least tenfold. The principal consumer, however, has remained Western Europe, and while American investments have increased to more than $\$ 1$ billion, the area's economic significance is clearly greater for Europe than the United States.

What has given North Africa a particularly unique status for the United States has not been its location, resources, or military capabilities but, rather, the quality of its leadership, the moderate political systems which have been implanted after independence, and the inclination of most North Africans to face problems of political development with a balanced sense of hope and limitation. As a result, U.S. foreign aid contributions--direct and indirectto Morocco, Tunisia, and Libya have been substantial. By conservative estimate, our aid has exceeded $\$ 1$ billion over the past two decades.

In providing this assistance, we have been caught in a serious policy dilemma. As pointed out by Professor Samuel Huntington:

In the past the US Government has been caught between two beliefs, each of which is undoubtedly supported by large elements of American opinion and each of which is in part true: first, that the people of a country have a right to shape their own political, economic and social institutions free from outside interference; and second that the most desirable society is a pluralistic one characterized by private enterprise, social equity and political democracy. ... ${ }^{1}$

These precepts do set up competing demands. Clearly, we are hopeful that other peoples will emulate our society and fashion political systems similar to our own. On the other hand, the question does arise as to the propriety of using assistance as leverage to induce the type of change we desire- both political and social.

On the whole, the United States has preferred to support a pragmatic approach, one in which our interests in North Africa are brought into rough balance with our aspirations. As a result, assistance, in all its various forms, has been provided a wide array of governments - republican and monarchical-supporting differing ideologies-socialist and mixed capitalist-socialistand espousing divergent foreign policy goals-nonaligned, neutralist, and proWestern. Throughout this period, however, our approach has been consistent and practical. We have forsworn direct intervention in local affairs, often in the face of momentary distractions and seeming setbacks. They have covered

1. Samuel P. Huntington, "Foreign Aid for What and for Whom," Foreign Policy, No. 2 (Spring 1971), p. 126. 
a broad spectrum over the past decade including: the division of North Africa into competing blocs as a result of the Congo crisis in 1960-61; the eruption of intramural rivalries and disputes over boundary questions, leading to the Moroccan-Algeria conflict of 1963; the subsequent intervention of the Soviet Union, which has become Algeria's main arms supplier; the Casablanca riots of 1965 , reflecting the economic frustrations of local workers and students, and the resultant assumption of extralegal powers by King Hasan in June 1965; the outbreak of anti-American violence in several North African urban centers following the defeat of Arab armies by Israel in 1967; and, of course, the abrupt termination of the Idrisid dynasty in 1969 at the hands of a small group of disaffected army officers.

Perhaps the severest disappointment for most observers has been the failure of the Maghribi states to form closer political ties. The basic ingredients for unity appeared to exist. Shared colonial experience, a common religious foundation, and proximity all seemed to favor close political association. Moreover, the leaders of most of North Africa's political formations had developed harmonious personal relations during the liberation struggle. All the early signs appeared to point toward close postindependence collaboration, if not some form of union.

This vocation for unity found its most concrete expression in the Tangier Conference of April 1958, at which spokesmen for the Istiqlal, National Liberation Front, and the Destour met to establish the outlines of a common approach to mutual problems. The conference recommended, inter alia, the creation of committees to insure greater coordination of policies. The cap stone was to be a consultative assembly of the Arab Maghrib and a permanent secretariat. However, co-operation soon fell apart in the Congo crisis, exacerbated by Morocco's territorial claims in the western Sahara and Tunisia's extension of diplomatic recognition to the Daddah government in Mauritania. In addition, personal rivalries and ideological differences widened the gap among the various leadership groups. While efforts to fashion close regional ties have revived in recent years, no appreciable progress has been registered to date. If anything, the decision of Libya's military leaders to enlist in a loose-jointed federation with Egypt and Syria in 1971 has been viewed as a check to revived Maghribi aspirations for regional association.

\section{A Serviceable Approach}

Current American policy in North Africa is neither activist nor Thermidorian. It avoids both extremes emphasizing, instead, the basic long-range interests of the West-close commercial and economic ties, support for peaceful resolution of local disputes, and provision of assistance to countries bent upon political and social growth. In pursuit of these interests, we have avoided undue bemusement over the origins of local regimes, their immediate political philosophies, or their evident shortcomings. The United States has supported in turn royalists and republicans, ideologues and pragmatists, irredentists and strict constructionists.

Does this suggest that our policy is beset by paradoxical befuddlement? Since paradox, like beauty, is often a part of the perspective of the beholder, such an assessment may not seem unreasonable. But what has mainly distinguished the U.S. approach to the area has been its consistency and serviceability rather than uncertainty and paradox.

Nowhere has this been more evident than in the case of Libya. For more 
than seventeen years, the United States closely identified with and provided substantial support for King Idris, despite the many apparent deficiencies of his regime.

King Idris came to power in 1951 with credentials that seemed impeccable. He had long opposed Italian colonial domination from his place of exile in Egypt; he had rallied Cyrenaican forces to the Allied cause during World War II and subsequently returned to Libya to be appointed Emir of Cyrenaica. In the latter capacity, Idris had been a tireless exponent of Libyan independence. A gentle patrician, he was also a claimant to recognition as a religious figure because of his position as leader of the Sanusi brotherhood, a confraternity founded by his grandfather in 1842. What made Idris' political primacy inevitable, however, was his acceptability among most Libyan political factions as a compromise leader, one without special axes to grind.

The political system implanted by Idris proved a curious blend of gentle authoritarianism and puritanical traditionalism. Idris, throughout this reign, insisted upon personal loyalty and support by his ministers for Libya's essential goal of independence. Whatever the deficiencies of the highly personalized system of government that the King perpetuated, he played a singular role in developing a sense of nationhood. For many Libyans, the King was for many years the personification of the Libyan state.

Social change can and frequently does give rise to new claimants to power. In the case of Libya, the precipitants of change were to be found in the discovery of oil, a historic occasion in 1959 that unleashed new political forces. The Idrisid regime found itself increasingly unable to cope, despite recourse to a lengthy procession of mediocre minis- ters. When the army intervened ten years later, surprisingly little popular resistance materialized, and the King, who was traveling abroad, took up his involuntary exile in Cairo.

The cynical observer could, of course, criticize the United States for having supported a losing cause. In doing so, he would ignore the essential success of a policy dedicated to the survival of Libya as a going concern, and the pivotal position of the King in providing the stability needed to draw the diverse segments of Libyan society together. Idris, despite his many frailties, afforded his countrymen an opportunity to fashion the bonds needed to make their nation endure. In the end, his fall from power is less significant than the impetus he provided to Libya's evolution as a nation.

The American contribution to this process was both material and substantial. To a large extent, our success, or lack thereof, should be measured not in terms of the political longevity of Idris, but in terms of the survival of Libya as a nation-state. Within this framework, the cynics must defer to history.

In a sense, we end as we began. Those foreign affairs specialists who are members of the "revisionist school" will continue to regard U.S. foreign policy as essentially the pursuit of imperialist objectives. They will evaluate our goals in North Africa as an attempt to superimpose American influence and values. Those who are not committed to a particular view may evaluate our role from a different perspective—our contribution to the political development of free nations. In the latter context, the United States has demonstrated in North Africa that it is prepared to support constructive governments and programs, not as an intrusive world power, but as a force for peaceful change. 